CASSOWARY 3 (1): 31 - 44

ISSN : 2614-8900

E-ISSN : 2622-6545

CProgram Pascasarjana Universitas Papua, https://pasca.unipa.ac.id/

\title{
Analisis peranan sektor pertanian dalam pertumbuhan ekonomi dan distribusi pendapatan di provinsi papua barat
}

\author{
Analysis of the role of agricultural sector in Economic growth and income \\ distribution in west papua province
}

\author{
Merry $^{1}$, Bambang Nugroho' ${ }^{2}$ Ihwan Tjolli ${ }^{2 *}$ \\ ${ }^{1}$ Badan Pusat Statistika, Provinsi Papua Barat \\ Jalan Trikora Sowi IV, Manokwari, 98315 Indonesia \\ ${ }^{2}$ Program Studi S2 Pertanian, Program Pascasarajana, Universitas Papua \\ Jalan Gunung Salju, Amban, Manokwari, Papua Barat, 98314, Indonesia
}

*Email: hwantj@yahoo.co.id

\begin{abstract}
This study aims to analyze the contribution of agricultural sector to Gross Domestic Product (GDP), employment, and economic growth, analyze/calculate the amount of income inequality that happened, and analyze/identify the role of the agricultural sector towards the income distribution in districts/cities and economic growth in West Papua Province. This research was conducted in the province of West Papua by collecting data at BPS-Statistics Indonesia, Regional Planning Agency, Department of Agriculture of West Papua Province and other relevant technical agencies. The data required consist of GDP by sector of each district/city in West Papua Province by constant price, the total population by district / city, the percentage of the population aged over 15 years who worked under major employment field, and various other secondary data and some from the results of previous studies. The period of analysis in this study is 2000 to 2012. Data processing will be done with the help of software such as Microsoft Excel 2010, and SPSS. The analysis showed that the agricultural sector has a considerable contribution in the regional economy of West Papua province which accounted for an average of 37,96 percent per year of the total GDP. The result of analysis shows that income inequality has occurred in districts/cities in West Papua Province, one of which is caused by the agricultural sector. There is an increasing in the inequality index when the agricultural GDP is omitted. Inequality index with agricultural GDP is included is in the range of 0,20 and when agricultural GDP is eliminated the inequality index increases to about 0,40 . In other words, the agricultural sector has a significant role in reducing income inequality in districts/cities and is also able to increase the economic growth of West Papua Province. The result of a positive correlation (0.928) is present between the share of agricultural GDP and employment, the decreasing of the share of agricultural GDP was accompanied by the decreasing of agricultural employment. On the other hand, the relationship between the share of agricultural GDP and economic growth rate is negative (-0.659) or the opposite direction relationship.
\end{abstract}

Keywords: Economic Growth, Employment, Role of Agricultural Sector, GDP per capita. 
ABSTRAK: Penelitian ini bertujuan menganalisis kontribusi sektor pertanian terhadap PDRB, penyerapan tenaga kerja, dan laju pertumbuhan ekonomi, menghitung besarnya ketimpangan pendapatan, serta menganalisis/mengidentifikasi peranan sektor pertanian terhadap pemerataan pendapatan kabupaten/kota dan pertumbuhan ekonomi di Provinsi Papua Barat. Penelitian ini dilaksanakan di Provinsi Papua Barat dengan mengumpulkan data-data pada Badan Pusat Statistik, Badan Perencanaan Pembangunan Daerah, Dinas Pertanian dan instansi teknis terkait lainnya. Data yang diperlukan meliputi: PDRB menurut lapangan usaha kabupaten/kota se Papua Barat berdasarkan harga konstan, jumlah penduduk menurut kabupaten/kota, persentase penduduk berumur lebih dari 15 tahun yang bekerja menurut lapangan pekerjaaan utama. Periode analisis adalah tahun 20002012. Hasilnya menunjukkan bahwa sektor pertanian mempunyai kontribusi yang cukup besar dalam perekonomian daerah Provinsi Papua Barat yaitu menyumbang ratarata 37,96 persen per tahun dari total PDRB. Selanjutnya hasil analisis telah tejadi ketimpangan pendapatan kabupaten/kota di Provinsi Papua Barat yang salah satunya diakibatkan oleh sektor pertanian. Terjadi peningkatan indeks ketimpangan ketika PDRB sektor pertanian dihilangkan. Indeks ketimpangan ketika PDRB sektor pertanian diikutkan berada pada kisaran 0,20 dan ketika PDRB sektor pertanian dihilangkan maka indeks ketimpangan meningkat menjadi sekitar 0,40. Dengan kata lain sektor pertanian mempunyai peranan yang cukup besar dalam mengurangi ketimpangan pendapatan di kabupaten/kota se Provinsi Papua Barat, dan juga mampu meningkatkan pertumbuhan ekonomi Provinsi Papua Barat. Hasil korelasi positif $(0,928)$ terdapat pada hubungan share sektor PDRB pertanian dengan penyerapan tenaga kerja yaitu penurunan share PDRB sektor pertanian diiringi dengan penurunan penyerapan tenaga kerja di sektor peranian. Sedangkan hubungan antara share PDRB sektor pertanian dengan laju pertumbuhan ekonomi bernilai negatif $(-0,659)$.

Kata Kunci: Penyerapan Tenaga Kerja, Peranan Sektor Pertanian, Pertumbuhan Ekonomi, PDRB Perkapita.

\section{PENDAHULUAN}

Sebagai wilayah yang baru berkembang, pembangunan ekonomi di Provinsi Papua Barat memfokuskan pada pertumbuhan ekonomi yang tinggi tanpa memperhitungkan atau mempertimbangkan pemerataan distribusi pendapatan antara kabupaten/kota. Naufal (2010) menyatakan bahwa berdasarkan perhitungan Indeks Ketimpangan Williamsons yang membandingkan besaran Produk Domestik Regional Bruto (PDRB) perkapita antar Provinsi di Indonesia tahun 2000-2007, ketimpangan mencapai 0,85. Hal ini menggambarkan terjadi ketimpangan yang tinggi antar provinsi-provinsi di
Indonesia terutama dalam hal ketimpangan distribusi pendapatan per kapita penduduknya. Tingginya tingkat ketimpangan pendapatan mengindikasikan tidak meratanya pembangunan di Indonesia terutama di sektor ekonomi, sehingga ketimpangan di Indonesia sudah menjadi masalah serius seperti halnya negara yang sedang berkembang lainnya. Pertumbuhan ekonomi selalu dipusatkan pada peningkatan sektor modern yang cenderung sedikit dalam penyerapan tenaga kerja. Sektor tradisional seperti sektor pertanian yang mampu menyerap tenaga kerja dalam jumlah besar selama ini tersisihkan, sehingga sektor modern lebih cepat 
berkembang. Peningkatan yang cepat pada sektor modern menyebabkan kesenjangan antara sektor modern dan sektor tradisional. Untuk menanggulangi hal diatas perlu adanya strategi baru bagi pemerintah agar berorientasi pada pertumbuhan ekonomi sekaligus pemerataan.

Sektor pertanian merupakan sektor yang sangat penting dalam membangun perekonomian nasional, karena sektor pertanian memproduksi komoditi lokal yang sebenarnya faktor produksinya tidak bergantung pada impor. Di samping itu juga, sektor pertanian memiliki kontribusi yang cukup besar dalam penyerapan tenaga kerja di Indonesia apabila dibandingkan dengan sektor-sektor perekonomian lainnya. Penduduk yang berusaha di sektor pertanian tidak memerlukan keahlian dan keterampilan khusus seperti di sektor-sektor yang lain seperti industri atau pertambangan.

Instruksi Presiden Nomor 5 Tahun 2007 mengamanatkan agar dilakukan usaha percepatan pembangunan di Papua dan Papua Barat. Hal tersebut selanjutnya diteruskan dengan pembentukan Unit Percepatan Pembangunan Papua dan Papua Barat (UP4B). Aspek pembangunan yang dimaksud meliputi infrastruktur, diversifikasi pangan lokal, pengembangan bio-energi, kelembagaan pertanian, sumbedaya lahan, sumberdaya manusia, investasi swasta, agro industi dan pemasaran hasil pertanian.

Untuk mengukur tingkat kesejahteraan penduduk di suatu wilayah dapat dilihat dari besarnya angka perkapita dan rendahnya tingkat kemiskinan. Kondisi Perekonomian Provinsi Papua Barat saat ini cenderung belum sepenuhnya dapat mensejahterakan masyarakatnya. Hal tersebut ditandai oleh tingginya tingkat kemiskinan di Provinsi Papua Barat. Pada tahun 2012 (September), Provinsi Papua Barat menempati posisi kedua terendah setelah Provinsi Papua yaitu sebesar 27,04 \%. Data ini sangat fantastik jika dibandingkan dengan potensi lahan dan sumberdaya alam yang ada di Provinsi Papua Barat terutama di sektor pertanian.

Provinsi Papua Barat memiliki PDRB perkapita yang besar, namun persentase penduduk miskinnya juga sangat tinggi, hal ini mengindikasikan adanya ketimpangan pendapatan antar daerah. Menarik untuk dianalisis, karena ini menjadi suatu hal yang kontradiksi, dimana lahan yang tersedia untuk berusaha di sektor pertanian sangat luas, diharapkan sektor pertanian menjadi sektor unggulan di Provinsi Papua Barat. Potensi sektor pertanian ini diharapkan mampu menunjang pembangunan daerah dan mengurangi ketimpangan distribusi pendapatan penduduk yang selama ini terjadi di Provinsi Papua Barat.

Tujuan dari penelitian ini adalah: 1) Menganalisis kontribusi/peranan sektor pertanian terhadap PDRB, penyerapan tenaga kerja, dan laju pertumbuhan ekonomi di Provinsi Papua Barat, 2) Menganalisis/menghitung besarnya ketimpangan distribusi pendapatan yang terjadi di Provinsi Papua Barat, dan 3) Menganalisis/mengidentifikasi kontribusi/peranan sektor pertanian terhadap pemerataan pendapatan dan partumbuhan ekonomi di Provinsi Papua Barat.

\section{BAHAN DAN METODE}

Penelitian ini dilaksanakan di Provinsi Papua Barat selama 1 (satu) bulan dengan mengumpulkan data-data pada Badan Pusat Statistik, Badan Perencanaan Pembangunan Daerah, Dinas Pertanian Provinsi Papua Barat, dan instansi teknis terkait lainnya.

Beberapa tahapan analisis yang dilakukan dalam penelitian ini, yaitu peranan sektor pertanian dalam mengurangi ketimpangan pendapatan antar 
kabupaten/kota di Provinsi Papua Barat, sumbangan sektor pertanian terhadap PDRB, kontribusi sektor pertanian dalam penyerapan tenaga kerja, dan kontribusi sektor pertanian terhadap laju pertumbuhan ekonomi di Provinsi Papua Barat. Analisis ketimpangan distribusi pendapatan antar kabupaten/kota di Provinsi Papua Barat, dan analisis peranan sektor pertanian dalam mengurangi ketimpangan distri-busi pendapatan dan pertumbuhan ekonomi Provinsi Papua Barat. Pengolahan data dilakukan dengan bantuan software Microsoft Excel 2010, dan SPSS, sedangkan analisis data dilakukan sebagai berikut:

Formula yang digunakan untuk menghitung sumbangan sektor pertanian terhadap PDRB Provinsi Papua Barat adalah:

$P_{i t}=\frac{S_{i t}}{T_{t}} \times 100 \%$

Keterangan:

$P_{i t}=$ Besarnya kontribusi sektor pertanian pada tahun ke- $t(\%)$

$S_{i t}=$ PDRB sektor pertanian pada tahun ke- $t$ (rupiah)

$T_{t}=$ Total PDRB pada tahun- $t$ (rupiah)

Untuk menghitung besarnya pertumbuhan sektor pertanian selama jangka waktu tertentu dapat digunakan formula:

$G_{i t}=\left(\frac{P_{i t}}{P_{i t-1}} \times 100 \%\right)-100$

Keterangan:

$\mathrm{G}_{\mathrm{it}}=$ Pertumbuhan sektor pertanian pada tahun ke- $t$ (\%)

$\mathrm{P}_{\mathrm{it}}=$ Besarnya PDRB sektor pertanian pada tahun ke- $t$ (rupiah)

$\mathrm{P}_{\mathrm{it}-1}=$ Besarnya PDRB sektor pertanian pada tahun ke-t- 1 (rupiah)
Dalam penelitian ini diakukan dua uji analisis korelasi. Untuk melihat peran sektor pertanian terhadap ketimpangan pendapatan dilakukan analisis korelasi antara PDRB sektor pertanian dengan Indeks Ketimpangan, dimana:

$x=$ PDRB sektor pertanian, (rupiah)

$y=$ Indeks Ketimpangan

Selanjutnya untuk melihat kontribusi sektor pertanian terhadap pertumbuhan ekonomi, dilakukan analisis korelasi antara kontribusi/ peranan sektor pertanian dengan PDRB per kapita, dimana:

$$
\begin{aligned}
& \mathrm{x}=\text { PDRB sektor pertanian (rupiah) } \\
& \mathrm{y}=\text { PDRB per kapita (rupiah) }
\end{aligned}
$$

Jika $r$ mendekati angka 1 atau -1 maka korelasi yang terjadi akan semakin kuat baik positif maupun negative, sebaliknya jika semakin mendekati 0 , korelasi yang terjadi semakin lemah.

\section{HASIL DAN PEMBAHASAN}

A. Sumbangan Sektor Pertanian Terhadap PDRB, Penyerapan Tenaga Kerja, Dan Laju Pertumbuhan Ekonomi Provinsi Papua Barat

Sumbangan sektor pertanian tergolong cukup besar bila dibandingkan dengan sumbangan sektor-sektor lain. Sektor pertanian hampir mendominasi seluruh perekonomian kabupaten/kota di Provinsi Papua Barat. Pada Tabel 7. Terlihat bahwa sektor pertanian tumbuh rata-rata $37,96 \%$ per tahun, sementara laju pertumbuhan sektor pertanian tumbuh rata-rata sebesar $4,15 \%$ per tahun, laju pertumbuhan ekonomi tanpa migas rata-rata sebesar 7,88\% per tahun.

Berdasarkan Tabel 1, apabila dilihat dari tahun 2000-2012, maka peranan sektor pertanian puncaknya berada pada tahun 2000 sebesar 45,29\%, 
sedangkan yang terendah berada pada tahun 2011 yaitu sebesar 27,68\%. Laju pertumbuhan sektor pertanian tahun 2000 - 2012 tertinggi pada tahun 2011 sebesar 10,21\%, sedangkan yang terendah pada tahun 2004 yaitu sebesar $6,29 \%$, Peranan sektor pertanian, laju pertumbuhan sektor pertanian serta laju pertumbuhan ekonomi tanpa migas sejak tahun 2000-2012 berfluktuasi dan menurun.

Pola penurunan peranan sektor pertanian juga terjadi pada rentang tahun 2000-2012. Pada tahun 2012, peranan sektor pertanian hanya $27,68 \%$ atau turun sekitar $20 \%$ apabila dibandingkan pada tahun 2000. Menurut Boediono
(1999) bahwa pertumbuhan ekonomi merupakan suatu proses dimana perekonomian akan berkembang atau berubah dari waktu ke waktu. Jika dilihat PDRB seluruh sektor terdapat pergeseran peranan yaitu penurunan peran sektor pertanian dan peningkatan di sektor lainnya. Peranan sektor pertanian semakin menurun dalam kue ekonomi Papua Barat padahal sektor ini berkontribusi besar terhadap penyerapaan tenaga kerja dan tinggi rendahnya ketimpangan distribusi pendapatan. Walaupun peranan sektor pertanian semakin menurun tetapi sektor pertanian menjadi penting bagi sebagian besar masyarakat di Provinsi Papua Barat.

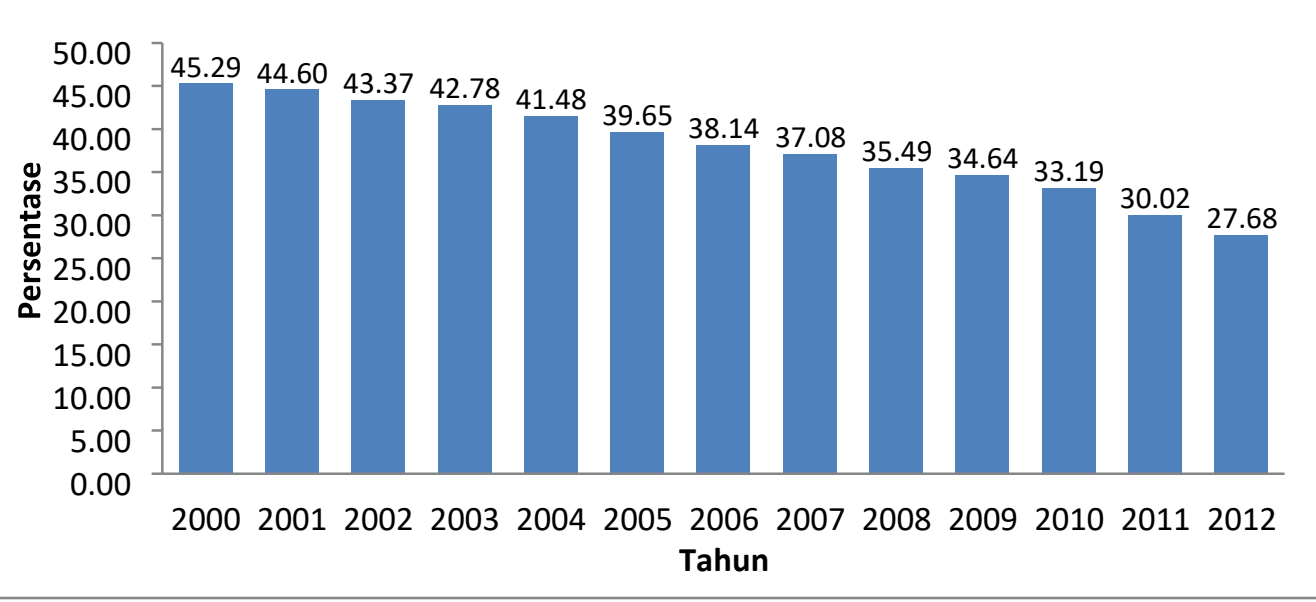

Gambar 2. Share PDRB Sektor Pertanian di Papua Barat Tahun 2000-2012 (Tanpa Migas)

Tabel 1. Peranan sektor pertanian terhadap laju pertumbuhan ekonomi Provinsi Papua Barat Tahun 2000-2012 (\%).

\begin{tabular}{|c|c|c|c|}
\hline \multirow{2}{*}{ Tahun } & \multirow{2}{*}{ Peran Sektor Pertanian } & \multicolumn{2}{|c|}{ Laju Pertumbuhan } \\
\cline { 3 - 4 } & & Sektor Pertanian & Sektor Ekonomi \\
\hline 2000 & 45,29 & & \\
\hline 2001 & 44,60 & 4,89 & 6,38 \\
\hline 2002 & 43,37 & 5,46 & 7,49 \\
\hline 2003 & 42,78 & 5,07 & 7,06 \\
\hline 2004 & 41,48 & 3,91 & 6,29 \\
\hline 2005 & 39,65 & 2,05 & 6,83 \\
\hline 2006 & 38,14 & 3,29 & 7,36 \\
\hline 2007 & 37,08 & 5,22 & 8,61 \\
\hline 2008 & 35,49 & 6,89 & 9,25 \\
\hline 2009 & 34,64 & 3,83 & 9,18 \\
\hline
\end{tabular}




\begin{tabular}{|c|c|c|c|}
\hline 2010 & 33,19 & 6,08 & 8,52 \\
\hline 2011 & 30,02 & 1,66 & 10,21 \\
\hline 2012 & 27,68 & 1,48 & 7,41 \\
\hline Rata-rata & 37,96 & 4,15 & 7,88 \\
\hline
\end{tabular}

Sumber: Diolah dari Data BPS (2013)

Tabel 2. Rata-Rata Kontribusi Sektor Pertanian terhadap Laju Pertumbuhan Ekonomi Kabupaten/Kota se Provinsi Papua Barat Tahun 2000-2012 (\%)

\begin{tabular}{lcc}
\hline Kabupaten/Kota & $\begin{array}{c}\text { Kontribusi Sektor Pertanian } \\
\text { terhadap PDRB (tanpa migas) }\end{array}$ & $\begin{array}{c}\text { Laju Pertumbuhan Ekonomi } \\
\text { PDRB (tanpa migas) }\end{array}$ \\
\hline Fakfak & 30,54 & 6,52 \\
Kaimana & 54,60 & 7,70 \\
Teluk Wondama & 77,10 & 9,47 \\
Teluk Bintuni & 60,87 & 7,97 \\
Manokwari & 37,51 & 8,14 \\
Sorong Selatan & 54,37 & 4,49 \\
Sorong & 42,97 & 4,29 \\
Raja Ampat & 76,05 & 3,45 \\
Tambrauw & 62,40 & 4,49 \\
Maybrat & 54,63 & 6,51 \\
Kota Sorong & 14,43 & 7,70 \\
\hline
\end{tabular}

Sumber: Diolah dari Data BPS (2013)

Dari Tabel 2 terlihat bahwa kontribusi/peranan sektor pertanian terhadap pembentukan PDRB tanpa migas provinsi/kabupaten/kota se Provinsi Papua Barat cenderung mendominasi. Kabupaten Teluk Wondama memiliki kontribusi tertinggi untuk sektor pertaniannya terhadap pembentukan PDRB di mana Kabupaten Teluk Wondama termasuk kabupaten penghasil tanaman bahan makanan seperti padi, tanaman sayuran dan lain-lain, disusul berturut-turut Kabupaten Raja Ampat di mana untuk Kabupaten Raja Ampat lebih di dominasi oleh tingginya produksi hasil-hasil perikanan dan juga tanaman bahan makanan, Kabupaten Tambraw sebagai kabupaten pemekaran dari Kabupaten Sorong juga memberikan kontribusi yang besar terhadap pembentukan PDRB. selanjutnya Kabupaten Teluk Bintuni sebagai daerah penghasil produksi hasil perikanan (udang) dan juga sentra produksi tanaman bahan makanan (daerah transmigrasi), Kabupaten Maybrat yang terkenal dengan penghasil kacang-kacangan, Kabupaten Kaimana yang terkenal dengan produksi hasil laut untuk eksport, Kabupaten Sorong Selatan yang cukup banyak mempro-duksi padi dan sagu, juga hasil perikanan lainnya seperti udang, kepiting, Kabu-paten Sorong sebagai lumbung padi di Provinsi Papua Barat dan juga penghasil produk peternakan, Kabupaten Manok-wari karakteristik daerahnya hampir sama dengan Kabupaten Sorong dari sektor pertaniannya, Kabupaten Fakfak yang terkenal dengan julukan "Kota Pala" sementara Kota Sorong sebagai kota jasa berada pada urutan terendah.

Tingginya peranan sektor pertanian di Kabupaten Teluk Wondama disebabkan oleh produksi hasil-hasil pertanian yang meningkat dari tahun ke tahun, sementara rendahnya kontribusi sektor pertanian di Kota Sorong 
dikarenakan mayoritas penduduknya memiliki aktivitas ekonomi di sektor perdagangan dan minimnya lahan pertanian dibandingkan kabupaten lain.

Tujuh dari sebelas kabupaten memiliki rata-rata share sektor pertanian terhadap PDRB di atas $50 \%$, hal ini membuktikan bahwa peran sektor pertanian dalam perekonomian Provinsi Papua Barat sangatlah kuat. Luas lahan yang potensial untuk dikembangkan di beberapa kabupaten juga turut berperan dalam menghasilkan produksi hasil pertanian.

\section{B. Peranan Sektor Pertanian Dalam Distribusi Pendapatan Dan Pertumbuhan Ekonomi Provinsi Papua Barat}

Dalam menganalisis peranan sektor pertanian terhadap ketimpangan pendapatan kabupaten/kota di Provinsi Papua Barat, dapat dilakukan dengan membandingkan besarnya Indeks Williamson dengan PDRB dari sektor pertanian (seluruh sektor) dalam perhitungan dengan besarnya Indeks Williamson tanpa PDRB dari sektor pertanian, Selisih antara dua Indeks tersebut akan mencerminkan peranan sektor pertanian dalam mengurangi ketimpangan distribusi pendapatan di Provinsi Papua Barat.

Dari grafik pada Gambar 3 terlihat bahwa ketimpangan distribusi pendapatan di Provinsi Papua Barat berfluktuasi dari tahun ke tahun, pada tahun 2000 tingkat ketimpangan di Provinsi Papua Barat sebesar 0,221, tahun 2001 sebesar 0,218 , nilai tertinggi terjadi pada tahun 2010 dimana indeks ketimpangan sebesar 0,278, namun menurun pada tahun 2011 dan 2012 sebesar 0,276 dan 0,256. Dari hasil perhitungan menunjukkan bahwa keterbandingan antar wilayah hampir merata, ini berarti bahwa pembangunan pertanian di Provinsi Papua Barat cukup baik, angka indeks Williamson berfluktuasi dipengaruhi oleh angka PDRB sektor pertaniannya yang juga berfluktuasi. Produksi hasil-hasil pertanian dari tahun ke tahun belum menunjukkan peningkatan yang stabil, hal ini bisa disebabkan karena kurangnya penduduk yang berusaha di sektor pertanian. Indeks Williamson tersebut juga menunjukkan bahwa terdapat kecenderungan ketimpangan distribusi pendapatan relatif rendah atau pertumbuhan ekonomi relatif merata untuk kabupaten/kota di Provinsi Papua Barat dari tahun 2000-2012. Hal ini ditunjukkan oleh nilai indeks dari tahun 2000 - 2012 berada pada kisaran angka 0,20. Todaro (1999) mengatakan bahwa pada tahap awal pertumbuhan ekonomi suatu daerah, distribusi pendapatannya akan cenderung memburuk, namun selanjutnya akan mulai membaik, sebagaimana yang terjadi di beberapa kabupaten/kota se Provinsi Papua Barat.

Dari grafik pada Gambar 4 belum sepenuhnya bisa menentukan peran sektor pertanian dalam melihat ketimpangan distribusi pendapatan sehingga perlu dilakukan penghitungan Indeks Williamson tanpa menyertakan PDRB Sektor Pertanian.

Dari grafik Gambar 4 terlihat bahwa ketimpangan distribusi pendapatan di Provinsi Papua Barat masih berfluktuasi dari tahun ke tahun. Terlihat pula bahwa terjadi peningkatan nilai Indeks Williamson ketika PDRB sektor pertanian tidak dimasukkan dalam penghitungan. Pada tahun 2000 tingkat ketimpangan di Provinsi Papua Barat sebesar 0,430. Tahun 2001 turun menjadi sebesar 0,416. Nilai tertinggi terjadi pada tahun 2005 di mana indeks ketimpangan sebesar 0,587, namun menurun pada tahun 2006 menjadi 0,533. Pada tahun 2012, Indeks Williamson berada pada nilai 0,478 atau turun dibandingkan tahun sebelumnya. 
Indeks Williamson tersebut juga menunjukkan bahwa terdapat kecenderungan ketimpangan distribusi pendapatan relatif tinggi atau pertumbuhan ekonomi relatif tidak merata dibandingkan penghitungan Indeks Williamson dengan memasukkan PDRB sektor pertanian untuk kabupaten/kota di Provinsi Papua Barat dari tahun 20002012. Hal ini ditunjukkan oleh nilai indeks dari tahun 2000 - 2012 berada pada kisaran angka 0,40. Walaupun terlihat ada perbedaan Indeks Williamson dengan Sektor Pertanian (IWP) dan Indeks Williamson Tanpa Sektor Pertanian (IWTP), tetapi perlu diuji lebih lanjut apakah nilainya signifikan secara statistik atau tidak.

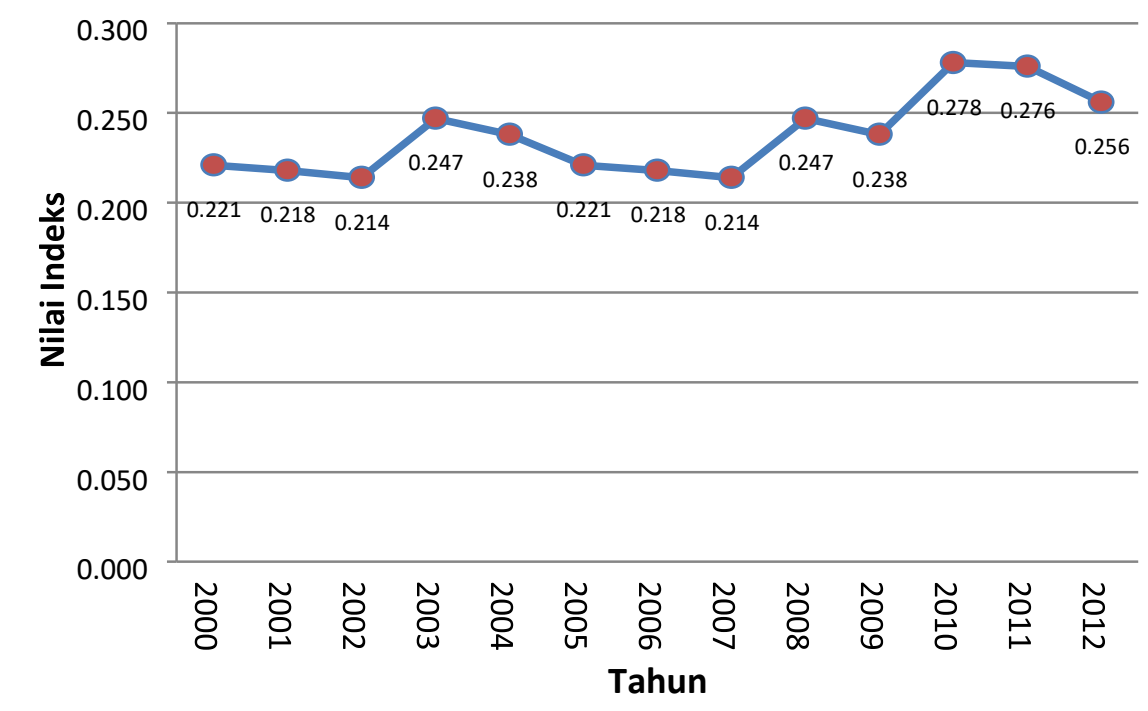

Gambar 3. Indeks Ketimpangan PDRB Sektor Pertanian di Provinsi Papua Barat Tahun 2000-2012

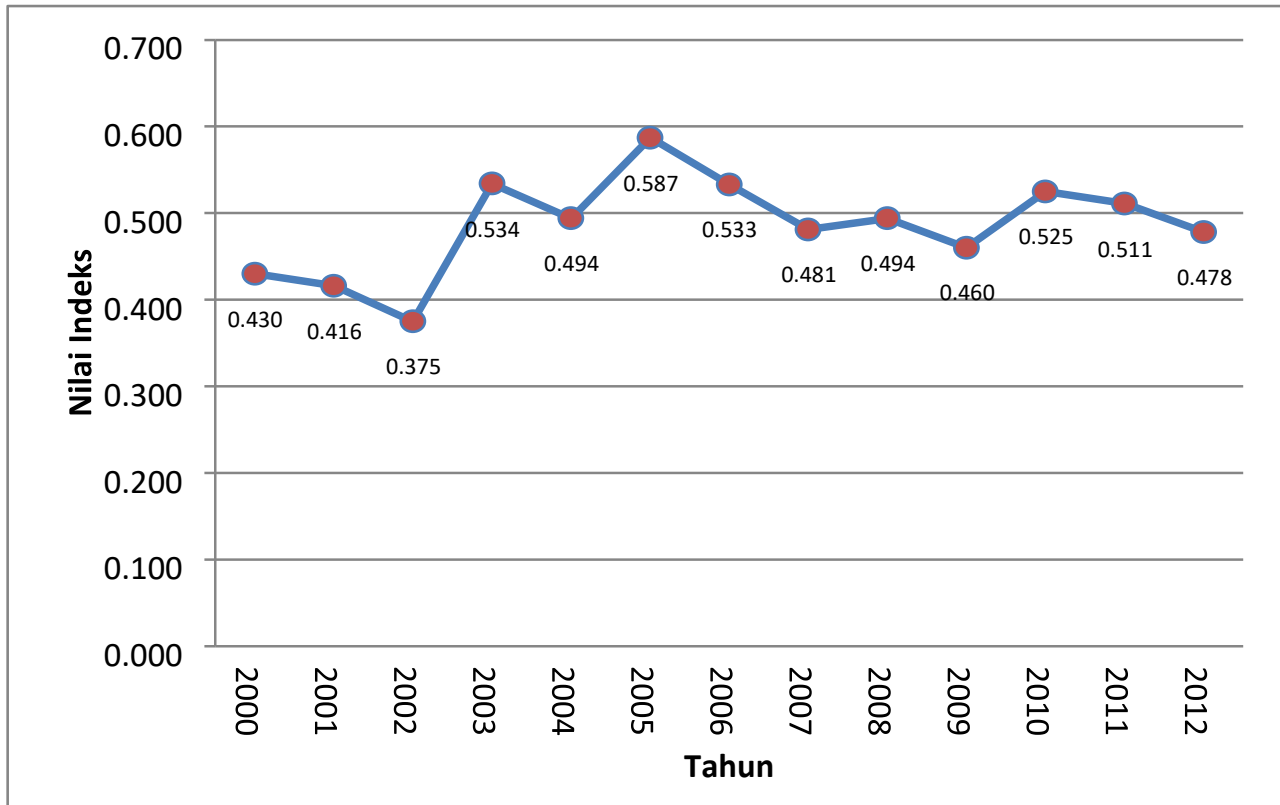

Gambar 4. Indeks Ketimpangan Tanpa PDRB Sektor Pertanian di Provinsi Papua Barat Tahun 2000-2012 
C. Pengujian Perbedaan Indeks Williamson Dengan PDRB Sektor Pertanian Dan Tanpa Sektor Pertanian Di Provinsi Papua Barat Dari perhitungan pada Tabel 3, terlihat bahwa angka Indeks Ketimpangan dengan memasukkan PDRB sektor pertanian dalam perhitungan nilainya lebih kecil dibandingkan dengan Indeks Ketimpangan tanpa memasukkan PDRB sektor pertanian atau dengan kata lain ada perbedaan antara kedua hasil penghitungan tersebut. Sehingga peneliti menyusun hipotesis bahwa memang ada perbedaan antara Indeks Williamson dengan PDRB Sektor Pertanian dan Tanpa Sektor Pertanian. Selanjutnya kedua nilai indeks tersebut akan diuji dengan uji statistik yaitu uji-t.

Tabel 3. Peranan Sektor Pertanian terhadap Laju Pertumbuhan Ekonomi Provinsi Papua Barat Tahun 2000-2012.

\begin{tabular}{lcc}
\hline Tahun & IWP & IWTP \\
\hline 2000 & 0,221 & 0,430 \\
2001 & 0,218 & 0,416 \\
2002 & 0,214 & 0,375 \\
2003 & 0,247 & 0,534 \\
2004 & 0,238 & 0,494 \\
2005 & 0,221 & 0,587 \\
2006 & 0,218 & 0,533 \\
2007 & 0,214 & 0,481 \\
2008 & 0,247 & 0,494 \\
2009 & 0,238 & 0,460 \\
2010 & 0,278 & 0,525 \\
2011 & 0,276 & 0,511 \\
2012 & 0,256 & 0,478 \\
\hline Sumber
\end{tabular}

Sumber : Diolah dari Data BPS (2013)

Setelah dilakukan uji dua nilai tengah berpasangan terbukti signifikan pada taraf nyata 5 persen (Lampiran 31) menunjukkan bahwa ada perbedaan nilai Indeks Williamson dengan memasukkan
PDRB sektor pertanian dan tanpa PDRB sektor pertanian.

Sektor pertanian memiliki dampak pada ketimpangan distribusi pendapatan di Provinsi Papua Barat karena sebagian besar masyarakat berusaha di sektor pertanian. Hal ini terbukti dari sebagian besar (7 dari 11) kabupaten/kota di Provinsi Papua Barat memiliki share sektor pertanian di atas 50\%. Hasil penghitungan Indeks Williamson ini diharapkan dapat menjadi rujukan bahwa sektor pertanian di Provinsi Papua Barat sangat penting dan perlu dikembangkan lebih lanjut. Pemerintah perlu mengembangkan sektor pertanian misalnya dengan membangun dan mendukung wilayah pusat pertanian (Agropolis) dengan wilayahwilayah pendukung sektor pertanian di sekitarnya. Wilayah Agropolis merupakan wilayah yang memadukan/mengintegrasikan usaha-usaha pada industri pengolahan maupun perdaga-ngan dengan menggunakan bahan baku yang berasal dari sektor pertanian. Sehingga diharapkan wilayah tersebut dapat meningkatkan produktivitas sektor pertanian, menyerap tenaga kerja lebih banyak dan hasil akhirnya berdampak pada peningkatan pertumbuhan ekonomi dan peningkatan pendapatan masyarakat, tentunya butuh sinergi antara pemerintah dan masyarakat.

\section{Peranan Serta Korelasi Kontribusi Sektor Pertanian Terhadap PDRB Per Kapita, Laju Pertumbuhan Ekonomi Dan Penyerapan Tenaga Kerja Di Provinsi Papua Barat}

Peningkatan sektor pertanian tanpa diikuti oleh peningkatan sektor lainnya yang mendukung produksi hasil pertanian di kabupaten/kota yang didominasi oleh sektor pertanian tidak 
akan optimal meningkatkan pertumbuhan ekonomi, jadi diperlukan juga peningkatan pada sektor hulu-hilirnya (agroindustri) agar nilai tambah yang dicapai pada daerah yang didominasi sektor pertanian akan lebih besar. Kondisi belum dioptimalkannya peningkatan sektor huluhilir Provinsi Papua Barat disajikan pada Gambar 5.

Dari grafik terlihat bahwa peningkatan laju pertumbuhan ekonomi tidak diiringi oleh peningkatan share PDRB pertanian. Tahun 2001-2012, share PDRB pertanian terus menurun. Jika kita lihat secara keseluruhan PDRB tiap sektor, maka akan terlihat bahwa terjadi pergeseraan share antar sektor yaitu semakin menurunnya PDRB sektor pertanian dan semakin meningkatnya share sektor lainnya terutama sektor industri dan pengolahan.

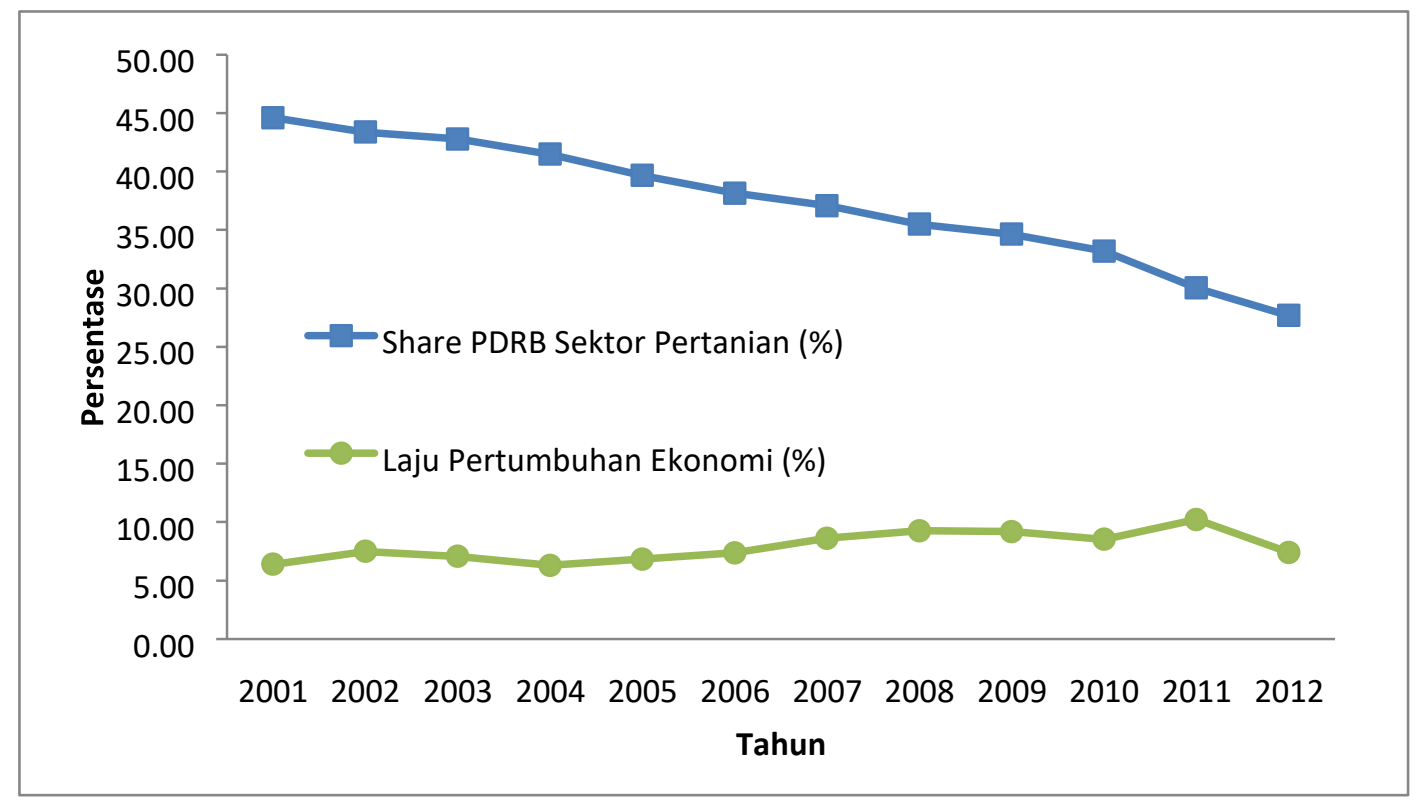

Gambar 5. Share PDRB Sektor Pertanian dengan Laju Pertumbuhan Ekonomi di Provinsi Papua Barat Tahun 2001-2012

\section{E. Korelasi Kontribusi Sektor Pertanian dengan Penyerapan Tenaga Kerja Sektor Pertanian}

Pergeseran karakteristik ekonomi di Provinsi Papua Barat juga terlihat dari pola penyerapan tenaga kerjanya. Masyarakat lebih cenderung beralih profesi dari sektor pertanian ke sektor industri, perdagangan dan jasa karena mereka beranggapan bahwa sektor pertanian "kurang menjanjikan" untuk kesejahteraan. Kondisi tersebut dapat dilihat dari grafik berikut.

Dari grafik dapat dilihat bahwa terjadi penurunan penyerapan tenaga kerja di sektor pertanian pada tahun 2007-2012. Jika kita lihat penyerapan tenaga kerja pada setiap sektor terjadi pergeseran penyerapan tenaga kerja. Sektor pertanian mengalami kecenderungan tidak diminati atau dianggap tidak menjanjikan dibandingkan dengan sektor lain dari tahun ke tahun. Pada tahun 2007-2012, penurunan juga terjadi pada share PDRB sektor pertanian. Dari grafik peneliti menyusun hipotesis bahwa ada hubungan antara penurunan share PDRB sektor pertanian dengan penyerapan tenaga kerja sektor pertanian. 
Berdasarkan uji korelasi (Lampiran 32), menunjukkan bahwa ada hubungan yang signifikan antara kontribusi atau share PDRB sektor pertanian dengan penyerapan tenaga kerja di sektor pertanian. Korelasi menunjukkan nilai 0,928 yang berarti ada hubungan kuat dan menunjukkan arah positif atau searah. Korelasi tersebut termasuk kuat karena jika dilihat nilainya sudah berada diatas nilai 0,5 dan mendekati 1. Hal ini juga menunjukkan bahwa perlu perhatian khusus terhadap sektor pertanian di Provinsi Papua Barat karena sektor pertanian merupakan sektor yang share nya paling besar (PDRB tanpa migas) di Provinsi Papua Barat.

Sesuai dengan karakteristik sebagian besar masyarakat di Provinsi Papua Barat, sektor pertanian merupakan lapangan usaha yang mampu menyerap tenaga kerja besar sehingga jika terjadi pergeseran share sektor pertanian ke sektor lain belum tentu menandakan hal baik. Pergeseran share sektor pertanian belum tentu juga beriringan dengan pergeseran tenaga kerja sektor tersebut ke sektor lain.

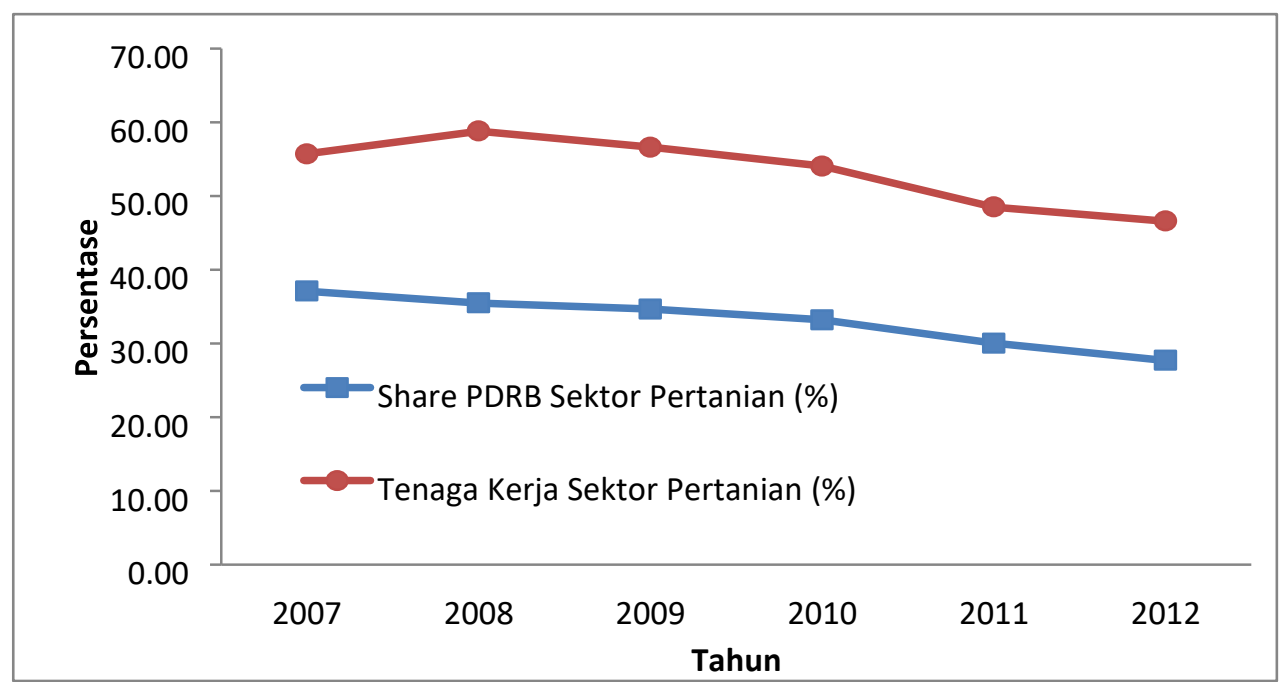

Gambar 6. Share PDRB Sektor Pertanian dengan Penyerapan Tenaga Kerja di Provinsi Papua Barat Tahun 2007-2012

\section{KESIMPULAN DAN SARAN Kesimpulan}

Berdasarkan hasil penelitian ini dapat disimpulkan bahwa:

1. Kontirbusi/peranan sektor pertanian cukup besar dalam perekonomian Provinsi Papua Barat yaitu menyumbang rata-rata $37,96 \%$ per tahun dari total PDRB tanpa migas, Sumbangan terbesar dari sektor ini terjadi pada tahun 2000 sebesar $45,29 \%$, sumbangan terkecil terjadi pada tahun 2012 yaitu $37,96 \%$, sedangkan pertumbuhan ekonomi sektor pertanian rata-rata hanya sebesar $7,88 \%$ per tahun, namun mampu menyerap tenaga kerja sekitar 53,36\% per tahun (2007-2012).

2. Telah tejadi ketimpangan distribusi pendapatan kabupaten/kota di Provinsi Papua Barat yang salah satunya diakibatkan oleh sektor pertanian. Apabila Sektor pertanian dihilangkan dalam perhitungan akan terjadi peningkatan indeks ketimpangan yaitu sebesar 0,40 sedangkan apabila PDRB sektor pertanian dimasukkan nilainya berada pada kisaran 0,20. Artinya adalah sektor pertanian mempunyai peranan yang cukup 
besar dalam mengurangi ketimpangan distribusi pendapatan kabupaten/kota di Provinsi Papua Barat, dan juga mampu meningkatkan partumbuhan ekonomi di Provinsi Papua Barat, walaupun belum tentu menurunkan angka kemiskinan, karena tumbuhnya sektor pertanian disebabkan oleh komoditinya banyak dimiliki oleh pemilik modal bukan oleh masyarakat apalagi masyarakat di pedesaan.

3. Analisis korelasi yang lain menunjukkan bahwa terjadi hubungan positif antara persentase PDRB sektor pertanian dengan PDRB per kapita. Hal ini menunjukkan bahwa kabupaten/kota yang didominasi oleh sektor pertanian cenderung memiliki PDRB per kapita yang tinggi dibandingkan kabupaten/kota yang didominasi oleh sektor bukan pertanian, dengan demikian sektor pertanian mampu meningkatkan pertumbuhan ekonomi di Provinsi Papua Barat. Hasil korelasi positif $(0,928)$ atau searah juga terdapat pada hubungan share sektor PDRB pertanian dengan penyerapan tenaga kerja yaitu penurunan share PDRB sektor pertanian diiringi dengan penurunan penyerapan tenaga kerja di sektor peranian. Sedangkan hubungan antara share PDRB sektor pertanian dengan laju pertumbuhan ekonomi bernilai negatif $(-0,659)$ atau berlawanan arah.

\section{Saran}

1. Sektor pertanian yang mempunyai kontribusi/peranan yang cukup besar dalam pembentukan PDRB di Provinsi Papua Barat, yang mana cukup banyak menyerap tenaga kerja, agar lebih diperhatikan, khususnya dalam hal penyelenggaraan programprogram pembangunan pertanian yang mengikutsertakan masyarakat sebagai pekerja/berusaha di sektor pertanian.

2. Ketimpangan distribusi pendapatan yang merata di Provinsi Papua Barat agar dipertahankan, tentunya harus ada sinergi yang kuat antara pemerintah dan masyarakat untuk meningkatkan produktifitas hasilhasil pertanian, sehingga dapat meningkatkan pertumbuhan ekonomi, yang akhirnya dapat mengurangi angka kemiskinan dan kemakmuran di Provinsi Papua Barat akan tercapai.

3. Perlu dukungan dari pemerintah bersama pihak swasta untuk mengembangkan industri-industri yang berbasis di pedesaan sehingga hasilhasil pertanian dapat dioleh menjadi barang jadi yang akhirnya akan memberikan nilai tambah bagi pembangunan pertanian di kabupaten/kota se Provinsi Papua Barat dan juga meningkatkan pendapatan masyarakatnya.

\section{DAFTAR PUSTAKA}

[BPS] Badan Pusat Statistik. 2009. Statistik Indonesia. 2009. BPS. Jakarta.

[BPS] Badan Pusat Statistik. 2009. Papua Barat Dalam Angka 2009. BPS Provinsi Papua Barat. Manokwari.

[BPS] Badan Pusat Statistik. 2010. Survei Sosial Ekonomi Nasional. Tahun 2010. BPS Provinsi Papua Barat. Manokwari.

[BPS] Badan Pusat Statistik. 2012. Papua Barat Dalam Angka Tahun 2012. BPS Provinsi Papua Barat. Manokwari. 
[BPS] Badan Pusat Statistik. 2012. Produk Domestik Regional Bruto Tahun 2012. BPS Provinsi Papua Barat. Manokwari.

[BPS] Badan Pusat Statistik. 2013. Papua Barat Dalam Angka Tahun 2013. BPS Provinsi Papua Barat. Manokwari.

[BPS] Badan Pusat Statistik. 2013. Indeks Pembangunan Manusia. Tahun 2013. BPS Provinsi Papua Barat. Manokwari.

[BPS] Badan Pusat Statistik. 2013. PDRB Papua Barat Menurut Lapangan Usaha Tahun 2013. BPS Provinsi Papua Barat. Manokwari.

Badan Perencanaan Pembangunan Daerah. 2013. Buku Saku Statistik Provinsi Papua Barat. BAPPEDA Provinsi Papua Barat, 2013.

Boediono. 1999. Teori Ekonomi Makro. Edisi Keempat. BPFE UGM. Yogyakarta.

Daniel dan Michael. 2002. Pengantar Ekonomi Pertanian. Penerbit Bumi Aksara, Jakarta.

Hendra. 2004. Peranan Sektor Pertanian dalam Mengurangi Ketimpangan Pendapatan Antar Daerah di Provinsi Lampung [skripsi]. Departemen Ilmu Ekonomi, Fakultas Ekonomi dan Manajemen, Institut Pertanian Bogor, Bogor.

Iqbal, M dan Sudaryanto. 2008. Tanggungjawab Sosial Perusahan (Corporate Social Responsibility) dalam Perspektif
Kebijakan Pembangunan Pertanian. Analisis Kebijakan Pertanian Volume 6 No. 2, Juni 2008

Kristiyanti, L. 2007. Analisis Sektor Basis Perekonomian dan Peranannya dalam Mengurangi Ketimpangan Pendapatan Kabupaten/Kota di Provinsi Jawa Timur [skripsi]. Fakultas Pertanian, Institut Pertanian Bogor, Bogor.

Mahesa, N.P. 2012. Analisis Pertumbuhan Ekonomi dan Ketimpangan Pendapatan antar kecamatan di Kabupaten Gianyar.

Mubyarto. 1995. Pengantar Ekonomi Pertanian. LP3ES. Jakarta.

Mubyarto. 1989. Pengantar Ekonomi Pertanian. LP3ES. Jakarta.

Naufal. 2010. Peranan Sektor Pertanian dalam Pertumbuhan Ekonomi dan Mengurangi Ketimpangan Pendapatan di Pemerintah Aceh. Skripsi. Departemen Ilmu Ekonomi Fakultas Ekonomi dan Manajemen.

Putra, L.D 2011. Analisis Pengaruh Ketimpangan Distribusi Pendapatan Terhadap Jumlah Penduduk Miskin di Provinsi Jawa Tengah Periode 2000-2007. Skripsi. Universitas Diponegoro. Semarang.

Prapti NSS, L. 2010. Keterkaitan Antara Pertumbuhan Ekonomi dan Distribusi Pendapatan (Studi Kasus 35 Kabupaten/Kota Jawa Tengah 20002005).TESIS. Universitas Andalas. 
Ratriadi, B 2009. Analisis Disparitas Pendapatan Dan Pertumbuhan Ekonomi Kabupaten/Kota Di Daerah Istimewa Yogyakarta Tahun 2003-2007. Universitas Negeri Semarang.

Richardsons, H. W. 1991. Dasar-Dasar Ilmu Ekonomi Regional.LP FEUI. Jakarta.

Sadono. 2004. Pengantar Teori Makro Ekonomi. Raja Grafindo Persada. Jakarta.

Samoelson, Paul A dan Nordhaus William D. 1997. Ekonomi. Edisi keXII Jilid I Terjemahan Jaka Wasana.Erlangga. Jakarta.

Todaro, M. P. Smith, S. C. 1999. Pembangunan Ekonomi di Dunia Ketiga. Jilid ke-1. Edisi Ke-8. Munandar dan Puji [penerjemah]. Erlangga, Jakarta.

Todaro, M. P. Smith, S. C. 2003. Pembangunan Ekonomi di Dunia Ketiga. Jilid ke-1. Edisi Ke-8. Munandar dan Puji [penerjemah]. Erlangga, Jakarta.

Todaro dan Michael. 2006. Ilmu Ekonomi Bagi Negara Sedang Berkembang. Suatu Pengantar Mengenai Dasar-Dasar Masalah dan Kebijaksanaan Dalam Pembangunan. Akademika Presindo. Jakarta.

Tripustika. 2005. Analisis Peranan serta Dampak Investasi Sektor Pertanian dan Sektor Industri Pengolahan terhadap Perekonomian Wilayah Provinsi Banten (Analisis Input-Output) [skripsi]. Fakultas Pertanian, Institut Pertanian Bogor, Bogor.
Wie, T.K. 1981. Pemerataan, Kemiskinan, Ketimpangan. Sinar Harapan, Jakarta. 